\title{
A Research Background of Global Value Chains
}

\author{
Sourish Dutta \\ PhD Student \\ Centre for Development Studies \\ Trivandrum, Kerala
}

\begin{abstract}
Purpose of this background note is to present some relevant research issues about India's GVC, such as degree of India's GVC linkages, by sector, by industry (preliminary analysis by GVC measures as well as in-depth econometric analysis), consequences of GVCs for economic prosperity i.e. industrial or economic upgrading (including trade-oriented upgrading and adaptation), the impact of GVCs on social upgrading, such as reflection on labour market dynamics (because social upgrading is not immediately associated with industrial or economics upgrading).
\end{abstract}

\section{Motivation}

A couple of major developments in the global economy, such as the revolution in ICT, deepening of trade liberalisation (and continuing transportation cost reduction) as well as some recent political developments are expanding the reach of globalisation through a gradual fragmentation of production processes across countries. Nowadays most of the products are composed of different designs and components produced by many suppliers (firms) with their operations in various countries, creating the global production networks. In fact, the typical "Made in" labels on manufactured goods have become old symbols of the past era. These days, more and more products are "Made in the World" rather than "Made in the USA" or "Made in China" (Antràs 2016).

Indeed, the global production (as a system of creating values in geographically separated tasks or phases) is eventually forming a world wide web of economic values or value added that explains the transitional structure of international trade and development. It is truly a new wave of globalisation, 
and it is termed as the global value chains (GVCs), creating the nexus among firms, workers and consumers around the globe. In general, from a industrial organisation perspective, value chains describe the sequence of productive (value-added) activities that capital and labour (or firms and workers) perform to bring a good or service from its conception to end use and beyond (Porter 1985, Sturgeon 2001). "Value chain analysis" is intended as the science of identifying bottlenecks and opportunities between different stages of production and tasks. It includes activities such as designing, administrative services, manufacturing, assembling, marketing, distribution and customer services. In the context of globalisation, these tasks that constitute a value chain have been carried out in inter-firm and intra-firm networks on a global scale (Gereffi et al. 2001, 2005). These value chains can be regional if the scope of production takes place within the same geographic region. From an economic perspective, the phenomenon of global value chains (GVCs) identifies a production structure in which tasks and business functions are distributed among several companies, globally, or regionally (Grossman \& Rossi-Hansberg 2012). The key features of GVCs are therefore the international dimension of the production process and the "contractualisation" of buyer and seller relationships, often across international borders (Antràs 2016). As a result, these international production networks are highly complex regarding geography, technology, and the variety of types of firms involved (from large retailers and highly large-scale mechanised manufacturers to small home-based production). Sometimes it may be impossible even to identify all the countries that are involved or the extent of their involvement (Gereffi \& Fernandez-Stark 2016). However, increasing international disintegration of production processes has been large enough to be salient in aggregate statistics.

GVC is truly a breakdown in the vertically-integrated mode of production-the so-called "Fordist" production. A variety of terms have been used to refer to this phenomenon: the "slicing of the value chain", "fragmentation of the production process", "disintegration of production", "delocalization", "vertical specialization", "global production sharing", "unbundling", "offshoring", "outsourcing" and many more (Antràs 2016, Feenstra 1998). We may use these terms interchangeably. Grossman \& Rossi-Hansberg (2012) rightly point out that the different tasks, rather than sectors, define the specialisation of countries in the value chains. The emergence of this new scenario is asking how an economy's production processes, producers and employees are connecting to the world trade and capturing the gains out of it regarding different dimensions of economic development.

We can use the GVC as the organising principle for the analysis of India's globalisation because it permits us to focus on India's global business strategy - including mass customisation, core competence, branding, and other barriers to entry, financialisation, and inducing competition among 
suppliers - that are crucial for corporate profitability. In fact, the value chain approach is particularly relevant for developing countries (especially for its firms) that seek to capture dynamic gains from world trade that come with economic and social upgrading within and across value chains (Milberg \& Winkler 2013).

Engagement in GVCs would not bring economic prosperity automatically. It requires much more value added from India's potential productive factors and upgrading quality \& quantity of those factors with a strong distributional aspect of socioeconomic opportunities and outcomes. In this situation, Milberg \& Winkler (2013) rightly suggest that to understand the welfare implications of India's global production networks, we need a shift in emphasis from static efficiency gains (resulting from specialisation and exchange) to the questions of the sources and uses of profits for firm investment, employment demand, and innovation. However, this analysis - undoubtedly focused on the production side - indicates that a heightened disembodying of the market forces will not promote a socially sustainable growth path for India. Therefore, we have to think about the policy options to maximise the dynamic gains from GVC engagement. Besides this, Gereffi \& Fernandez-Stark (2016) think about various tasks, i.e. decision about different types of industrial or economic upgrading (process, product, functional, or inter-sector), densification, social upgrading (employment, wages, or labour standards) and types of GVC governance (power relations) that India wants to pursue. In this context, evaluation of risks due to external shocks for surviving in the value chains is also relevant to consider.

\section{Global Background}

Global value chains (GVCs) can simply be thought of as world wide web of economic value. From a business organization perspective, value chains describe the sequence of productive (value-added) activities that capital and labor (or firms and workers) perform to bring a good or service from its conception to end use and beyond (Porter 1985, Sturgeon 2001). "Value chain analysis" is intended as the science of identifying bottlenecks and opportunities between different stages of production and tasks. Value chains are said to be "global" when they include steps, processes, and actors from at least two countries (Gereffi et al. 2001, 2005); they can be regional if the scope of production takes place within the same geographic region. From an economic perspective, the phenomenon of global value chains (GVCs) identifies a production structure in which tasks and business functions are distributed among several companies, globally, or regionally (Grossman \& Rossi-Hansberg 2012). The key features of GVCs are therefore the international dimension of the production process and 
the "contractualisation" of buyer and seller relationships, often across international borders.

Producing high-quality goods and services in GVCs involves more than simply trading goods and services internationally. GVCs, in effect, integrate the know-how of lead firms and suppliers of key components along all the stages of production and in multiple companies and offshore locations. Typically coordinated by lead firms, GVCs involve international trade flows within their networks of foreign affiliates (foreign direct investment), contractual partners (non-equity modes of investment), and arm's-length external suppliers (UNCTAD 2013). When Toyota makes car parts in Thailand, it does not rely on local know-how. Instead, it imports Toyota technology, management, logistics, and any other bits of know-how not available in Thailand, because Thai-made parts have to fit seamlessly with parts made in Japan and elsewhere. GVCs, in effect, "unbundle" factories by offshoring firmspecific know-how along the stages of production, and those international flows of know-how are a key reason why GVCs offer unprecedented development opportunities to participating countries (Taglioni \& Winkler 2016).

Actually, well-functioning supply chains-which define the physical movement of goods all along the value chain, including domestic and international segments - are a key concern in GVCs. This is the case because good logistics, which defines the art of managing the supply chain and includes good connectivity, streamlined procedures for imports and exports, and low cost of logistics services, is an important determinant of countries' ability to join and strengthen participation in GVCs and a key factor in determining the costs of sourcing from and supplying to global markets. Getting to the border is one of the most pervasive constraints for exports of firms in low- and middle-income countries (LMICs), while the costs of logistics services can be disproportionately high for smaller and younger firms or for more remote locations. Improving logistics is also where LMICs have the most potential to reduce trade costs, according to recent surveys. Finally, well-functioning trade facilitation measures enable GVC trade by reducing the time, cost, and uncertainty involved in importing and exporting (Taglioni \& Winkler 2016).

But most production processes do not happen in a sequence of dependent activities. Instead, they take place in more complex networks of production, in which participating firms are specialists in one activity and external international sourcing arrangements imbue inter-firm trade with characteristics similar to intra-group trade: better control from the center, higher levels of bilateral information flow, tolerance of asset specificity, and harmonization and immediate integration of business processes that increase the potential for foreign activities to integrate seamlessly with activities performed at home. Large brand-carrying multinational enterprises (MNEs), such as IBM, Siemens, and Toyota, nowadays rely on a complex web of suppliers, vendors, and service providers of all kinds 
and in multiple locations. At the same time, a set of highly influential global buyers gained scale and influence in the 1990s, including retailers such as Walmart and Tesco and branded merchandisers such as Nike, Zara, and Uniqlo (Feenstra \& Hamilton 2006). Building on successful experiments in the 1970s and 1980s by a handful of pioneering retailers, such as J. C. Penney and Sears, global buyers nowadays place huge orders with suppliers around the world without establishing any factories or farms of their own (Gereffi 1999, Ponte \& Gibbon 2005). Unlike traditional MNEs, where equity ties link headquarters with foreign affiliates, global buyers link to their suppliers through non-equity external sourcing ties. Often, intermediaries (for example, trading companies such as Hong Kong SAR, China's Li \& Fung) are used to link buyers to producers in multiple countries (Taglioni \& Winkler 2016).

To highlight the complexity of the interactions among global producers, recent literature makes reference to the concept of global production "networks" rather than "chains" (Henderson et al. 2002). Accordingly, in the more realistic metaphor of networks, links can be seen as connecting nodes, some more central and some more peripheral. However, in this massive production network capital and labor are not the only factors of production. "Ideas" can be singled out as a third factor of production, although they could also be understood as high-skilled labor input. In a global context, the value-added activity performed in one country crosses international borders in goods or services tasks. Different tasks of the value chain contain a different amount of such factors of production. For example, specialized workers tend to be necessary in higher value-added tasks of the GVC. In the automotive, electronics, and electrical appliance industries, ideas are more strongly embedded in the early pre-production stages, such as research and development and design, or in post-production (logistics, marketing, and branding), thus requiring such specialized workers in those tasks. In other industries, notably the craft based ones (such as furniture making), innovation development is maximized when ideas (product design) and manufacturing operations are joint (Buciuni et al. 2013, Pisano \& Shih 2009), because innovation in those sectors often stems from a bottom-up approach (Breznitz \& Murphree 2011).

Hence, by focusing on the sequences of tangible and intangible value-adding activities, from conception and production to end use, GVC analysis provides a holistic view of global industries both from the top down (for example, examining how lead firms "govern" their global-scale affiliate and supplier networks) and from the bottom up (for example, asking how these business decisions affect the trajectory of economic and social "upgrading" or "downgrading" in specific countries and regions). 


\section{Indian Background}

India has emerged as one of the fastest growing economies in the world through different levels of liberalisation. Yet this growth has brought mixed economic and social outcomes. On one hand, recent studies of IMF and OECD show rising total factor productivity in Indian industry and exports have become more skill and capital intensive, suggesting that some Indian products are moving into tiers of value chains and that companies are generating demand for more skilled workers. On the other hand, different authors draw attention to problems of unbalanced growth between regions, the persistence of low quality informal work and adverse impact of trade liberalisation on more employment-intensive sectors and agriculture (Mazumdar \& Sarkar 2008, Pal et al. 2007). Given the rising prominence of India within the global economy and the need to create economic as well as social upgrading for its diverse forces of production, I should know more about India's increasing engagement in GVCs and its potential to contribute toward more inclusive economic and social development.

In this global bandwagon, India has not been left behind. India's participation into GVCs in the last two decades concerning the foreign content of its exports was more than double from less than $10 \%$ in 1995 to $24 \%$ in 2011. It has been argued that the increased participation GVCs is associated with the hollowing out of Indian manufacturing. Indian industrial sector is experiencing a rising output but falling value-added in total production (declining real value added growth and employment elasticity) with the trend becoming more pronounced since the mid-1990s. Besides this, dualism concerning 'formal', 'informal', and 'missing-middle' along with limiting regulations pose unique challenges to the growth of India's manufacturing (Banga 2014b). As Indian industries are facing an intense competition (domestic as well as external) linked with the global production sharing, the obvious increased use of imported inputs has caused a generalised decline in national value-added share for merchandise and total exports (Banga 2014a, Goldar et al. 2017, Veeramani \& Dhir 2017). Although India's output grows and exports rise, if the domestic value added does not rise, then there would be no noticeable production-linked gains like employment generation, technology upgrading, and skill development (Banga 2014b). It requires much more value added from India's potential productive factors and upgrading quality \& quantity of those factors with a proper distributional aspect of socioeconomic opportunities and outcomes (Banga 2014a).

In this new scenario, it is pertinent to ask how an economy's production processes, producers and employees are connecting to the world trade and capturing the dynamic gains out of it? In summary, the critical issue is: how to make GVCs work for development in our economy as a whole? This can 
be analysed through three stages of GVC integration, i.e. entering GVCs, expanding and strengthening GVC participation, and turning GVC participation into sustainable development (Taglioni \& Winkler 2016). Firstly, India's entry in manufacturing GVCs depends on its performance in improving connectivity to international markets (logistics), ensuring cost competitiveness, improving drivers of investment (ease of doing business), protecting assets, improving quality of infrastructure and services. Secondly, expansion and strength of India's GVC participation are dependent on the absorptive capacity (includes innovation capacity) of local actors to reap the benefits from knowledge \& technology spillovers and its compliance with the process and product standards. Thirdly, India's GVC participation can be sustained by creating a world-class workforce through promoting skill development, social upgrading, and equitable distribution of opportunities and outcomes. Indeed, Milberg \& Winkler (2013) rightly suggest a shift in emphasis from static efficiency gains (resulting from specialisation and exchange) to the questions of the sources and uses of profits for firm investment, employment demand, and innovation to understand the welfare implications of India's global production networks (dynamic gains). Some studies show that the impact of participation in GVCs has been mixed. Upgrading opportunities do exist within GVCs, but those studies show that these opportunities tend to be concentrated among certain regions, sectors, firms and workers rather than widespread. Furthermore, gains for MNCs do not automatically translate into gains for workers (Posthuma \& Nathan 2010).

Participation in certain types of value chains has been found to provide latecomer firms with a fast track to process and product upgrading (Schmitz 2004). This effect was confirmed among some domestic firms supplying to GVCs which improved their manufacturing process, enhanced product quality and sophistication, and raised productivity. Such firms have attained conformity with international technical and quality standards and increased their demand for skilled formal sector workers. These upgraded firms were mainly medium and large companies which had existing existing productive capacities and product development expertise prior to engagement with GVCs, or were companies which operate in higher technology and knowledge-intensive sectors such as information technology (IT). Positive spillovers were captured by smaller firms with adequate cash flow to invest in improved production practices and product quality, which also increased their requirements for skilled labour. As a result, workers with technical and managerial skills, many semi-skilled workers, and those having opportunities to learn on-the-job also benefited (Posthuma \& Nathan 2010).

Besides this, various exclusionary pressure also exist. Ponte (2008) draws attention to an adverse incorporation of smaller firms and lower-skilled workers which has led to the embedding of informal and precarious work within GVCs. Firms in less technologically sophisticated sectors with limited 
productive capacities faced upgrading barriers as well. There are also costs involved in upgrading, such as investments to attain quality. and product standards in the agri-food sector (Memedović \& Shepherd 2008). In some forms of value chain governance, lead firms may prevent upgrading of suppliers, leading to 'lock-in' at low value-added, low-wage tiers (Schmitz 2006, Gibbon \& Ponte 2005). In fact, the cost-cutting nature of much GVCs and fluctuations in order schedules put pressures upon suppliers to compete by keeping costs low, which includes low-wage, flexible labour practices. While first-tier suppliers may gain under such circumstances, they survive by shifting price pressures and risks to smaller firms down their value chain. These practices are largely seen in the labour-intensive sectors such as garments, agriculture, and leather products as well as mediumtechnology sectors such as auto components. These negative externalities restrict profitability and inhibit the scope of for smaller firms to invest in equipment, new practices, and quality certification. While many jobs have been created, different studies provide evidence of the use of informal work throughout the tiers of many sectoral value chains, even among firms in the formal sector. Employment opportunities for women workers have been created in high tech sectors for more highly educated women, but the majority of these jobs are in labour-intensive, low-wage sectors (Posthuma \& Nathan 2010).

\section{References}

Antràs, P. (2016), Global Production: Firms, Contracts, and Trade Structure, Princeton University Press.

Banga, R. (2014a), 'Linking into global value chains is not sufficient: do you export domestic value added contents?', Journal of Economic Integration pp. 267-297.

Banga, R. (2014b), 'Trade facilitation and 'hollowing-out' of indian manufacturing', Economic and Political Weekly 49(40), 57-63.

Breznitz, D. \& Murphree, M. (2011), Run of the red queen: Government, innovation, globalization, and economic growth in China, Yale University Press.

Buciuni, G., Coro', G. \& Micelli, S. (2013), 'Rethinking the role of manufacturing in global value chains. An international comparative study in the furniture industry', Industrial and Corporate Change pp. 1-30.

Feenstra, R. C. (1998), 'Integration of trade and disintegration of production in the global economy', The journal of economic perspectives 12(4), 31-50. 
Feenstra, R. C. \& Hamilton, G. G. (2006), Emergent economies, divergent paths: Economic organization and international trade in South Korea and Taiwan, Vol. 29, Cambridge University Press.

Gereffi, G. (1999), 'International trade and industrial upgrading in the apparel commodity chain', Journal of international economics 48(1), 37-70.

Gereffi, G. \& Fernandez-Stark, K. (2016), Global value chain analysis: a primer, Duke CGGC (Center on Globalization, Governance \& Competitiveness).

Gereffi, G., Humphrey, J., Kaplinsky, R. \& Sturgeon*, T. J. (2001), 'Introduction: Globalisation, Value Chains and Development', IDS Bulletin 32(3), 1-8.

Gereffi, G., Humphrey, J. \& Sturgeon, T. (2005), 'The governance of global value chains', Review of International Political Economy 12(1), 78-104.

Gibbon, P. \& Ponte, S. (2005), Trading down: Africa, value chains, and the global economy, Temple University Press.

Goldar, B., Das, D. K., Sengupta, S. \& Das, P. C. (2017), 'Domestic value addition and foreign content: An analysis of india's exports from 1995 to 2011', ICRIER Working Paper 332.

Grossman, G. M. \& Rossi-Hansberg, E. (2012), ‘Task trade between similar countries’, Econometrica 80(2), 593-629.

Henderson, J., Dicken, P., Hess, M., Coe, N. \& Yeung, H. W.-C. (2002), 'Global production networks and the analysis of economic development', Review of International Political Economy 9(3), 436-464.

Mazumdar, D. \& Sarkar, S. (2008), Globalization, labor markets and inequality in India, Vol. 79, Idrc.

Memedović, O. \& Shepherd, A. (2008), Agri-food Value Chains and Poverty Reduction: Overview of Main Issues, Trands and Experiences, United Nations Industrial Development Organization.

Milberg, W. \& Winkler, D. (2013), Outsourcing economics: global value chains in capitalist development, Cambridge University Press.

Pal, P., Ghosh, J. et al. (2007), 'Inequality in india: A survey of recent trends', Economic and Social Affairs Working Paper 45.

Pisano, G. P. \& Shih, W. C. (2009), 'Restoring american competitiveness'. 
Ponte, S. (2008), 'Developing a vertical dimension to chronic poverty research: Some lessons from global value chain analysis', Chronic Poverty Research Centre Working paper .

Ponte, S. \& Gibbon, P. (2005), 'Quality standards, conventions and the governance of global value chains', Economy and Society 34(1), 1-31.

Porter, M. E. (1985), Competitive Advantage: Creating and sustaining superior performance, The Free Press.

Posthuma, A. \& Nathan, D. (2010), Labour in Global Production Networks in India, Oxford University Press.

Schmitz, H. (2004), Local upgrading in global value chains: recent findings, in 'International Convention Centre. Durban, South Africa', Vol. 21, pp. 1-8.

Schmitz, H. (2006), 'Learning and earning in global garment and footwear chains', The European Journal of development research 18(4), 546-571.

Sturgeon, T. J. (2001), How Do We Define Value Chains and Production Networks?, Technical Report 3, IDS Bulletin.

Taglioni, D. \& Winkler, D. (2016), Making Global Value Chains Work for Development, Vol. Trade and Development series, Washington, DC: World Bank.

UNCTAD (2013), 'Global value chains and development', World Investment Report 2013 .

Veeramani, C. \& Dhir, G. (2017), 'Domestic value added content of india's exports: Estimates for 112 sectors, 1999-2000 to 2012-13', IGIDR Working Paper. 